ACTA UNIVERSITATIS LODZIENSIS

FOLIA LITTERARIA POLONICA 5(35) 2016

http://dx.doi.org/10.18778/1505-9057.35.09

Anna Barańska-Szmitko*

\title{
The Capacities and Limitations of the Newspaper Column as a Tool for Creating the Image of Its Author
}

\section{Introduction}

The aim of this text is to present and verify the capacities and limitations of the newspaper column as a tool for creating the image of its author. It employs an interdisciplinary research approach. In order to meet this objective, a number of different perspectives on the genre's determinants present in Polish press studies are mentioned, and the features as to which the majority of researchers agree are indicated. A hypothesis proposed on this basis, which concerns the image of the author that is communicable to the reader, shall be verified by means of the empirical paradigm of rational constructivism $^{1}$; it employs a procedure ${ }^{2}$ in which respondents describe the authors of the columns they read (group one: Krzysztof Varga's columns, the other group: Szymon Hołownia's columns). The empirically obtained results were juxtaposed both with the features of the genre and the hypothesis in order to investigate which capacities and limitations in the creation of author's image are related to the genre.

* MA, e-mail: ankabaranska@poczta.fm; The University of Lodz, Faculty of Philology, Department of Journalism and Communication; ul. Pomorska 171/173, 90-236 Łódź.

${ }^{1}$ M. Fleischer, „Ogólna teoria komunikacji”, Wydawnictwo Uniwersytetu Wrocławskiego, Wroclaw 2007.

2 A. Siemes, „Jak badać komunikację”, Communication Design Magazine 2011, Vol. 1 [on-line], http://www.cd-magazine.uni.wroc.pl/artykul/jak_badac_komunikacje/ [access: 6.01.2014]; M. Grech, „Badanie wizerunku - metody ankietowe. Metodologia badan’”, in: „Badanie wizerunku: ludzie, marki, branże”, ed. M. Grech, Wydawnictwo Primum Verbum, Lodz 2012, pp. 11-26. 


\section{Features of the column as a genre}

The column is a form of journalistic expression characterized by a large extent of freedom, which poses difficulties in establishing its accurate definition and canonical model. Hence, researchers emphasize different features as essential, i.e. different determinants of the genre are given as dominant, determining the genre. These differing standpoints are mentioned below so as to show which features of a column stand out. To fully outline the genre, the determinants agreed on by most researchers are specified.

Piotr Stasiński ${ }^{3}$ observes that it is possible to define certain structural features of newspaper columns which stem from their history; however, they become unreliable in the precise description of the genre, and only the informality of this style should be recognized as a stable determinant; this informality allows for a farreaching subjectivity, which is supposed to ensure effective persuasion. The newspaper column was created in the early nineteenth century as a "section of the everyday press, featuring different cultural news provided in a playful tone to entertain readers". It was located "under the bar" at the bottom of a column, or on a separate page. This mosaic of texts was primarily supposed to intrigue the reader. With time, the column evolved to become a distinct genre. Its initial informality was retained, however. This genesis, according to Stasiński, affected the selection of structural features which establish the genre, such as: limited coherence, resulting from the compositional secondariness of originally distinct texts, "parasitizing" already raised issues, a penchant for parody related to its satirical and moralizing role, and stylistic freedom. Nevertheless, "the column's stability as a genre is very fragile, as far as the intratextual determinants alone are concerned", so for a researcher "the informality of the column is the genre's safeguard"'6. This informality, manifested in subjectivity, creates an impression that there are two subjects - the author and the reader, facilitating the text's influence on the latter. Thus, a column serves as a tool for persuasion, enabling the editorial team to express opinions they would never be able to - as P. Stasiński describes it - in any "official" genre of journalism.

Andrzej Niczyperowicz ${ }^{7}$ draws attention to the combination of journalism specific features of columns with the possibility, or even necessity, of

\footnotetext{
${ }^{3}$ Arguments below quoted after: P. Stasiński, „Poetyka i pragmatyka felietonu”, Zakład Narodowy im. Ossolińskich, Wroclaw 1982, pp. 5-17.

${ }^{4}$ Ibid., p. 5.

${ }^{5}$ Ibid., p. 10.

${ }^{6}$ Ibid.

${ }^{7}$ Quoted after: A. Niczyperowicz, „Przepis na felieton”, in: „Abecadło dziennikarza”, ed. A. Niczyperowicz, Kontekst, Poznan 1996, pp. 45-57. The same text - with minor changes - can be found in: A. Niczyperowicz, „Felieton. Piękny pasożyt”, in: „Dziennikarstwo od kuchni”, ed. A. Niczyperowicz, TS, Poznan 2001, pp. 81-94.
} 
employing an entire wealth of stylistic devices derived from literature. This genre of journalism must be related to social reality: "Undoubtedly, a column is a beautiful parasite. Sitting at the desk, the author chews on the information he read, the images he watched on TV, and the murmurs he heard on the radio. And he throws all of this together to create a text to the best of his talent"8. The preparation of the text requires literary virtuosity and must include concept-based constructions (the "basis"), an intriguing and perverse title, fitting punchlines and, finally, puns based on the sounds of words or sophisticated allusions.

Ewa Sławkowa ${ }^{9}$ also presents a unique approach, trying to organize stylistic indicators of the genre and pointing out that individual styles turn into styles of a genre. She relates the concept of style to:

primarily the acting subject - the author, understood [...] as an element of a particular text's structure, is nonetheless identified as the governing authority, which organizes and hierarchizes its different components. As a causative category which not only determines the structure of the genre, but also modifies this model in an individual way (often violating the norms) ${ }^{10}$.

So, Jarosław Krawczyk's texts represent and outline a baroque-polyphonic narrative style, Jerzy Trammer's proposals are marked by their miniature character, and Michał Ogórek relies on the linguistic model. In this way, "individual styles - styles of the genre, precisely, are being shaped"11 in separate realizations of the column.

Maria Wojtak ${ }^{12}$, on the other hand, draws attention to the existence of the newspaper column's adaptational models, i.e. the frequently used adaptation of different forms of journalism as well as of functional and literary genres. Hence, authors often use conventions characteristic of letters, speeches, guides, encyclopaedic entries or orders. The language of columns is also often stylized to resemble that used by a family, a small child, school textbook, feminist fundamentalist etc. The researcher emphasizes that "regardless of the formal

\footnotetext{
${ }^{8}$ A. Niczyperowicz, „Przepis”, op. cit., p. 46.

${ }^{9}$ Quoted after: E. Sławkowa, „Style współczesnego felietonu (Z zagadnień stylistyki gatunku)”, in: „Gatunki mowy i ich ewolucja”, Vol. 1: „Mowy piękno wielorakie”, ed. D. Ostaszewska, Wydawnictwo Uniwersytetu Śląskiego, Katowice 2000, pp. 305-315.

${ }^{10}$ Ibid., p. 307.

${ }^{11}$ Ibid., p. 313.

12 The ideas mentioned below quoted after: M. Wojtak, „Gatunki prasowe”, Wydawnictwo Uniwersytetu Marii curie-Skłodowskiej, Lublin 2004, pp. 202-237. See also: M. Wojtak, „Analiza gatunków prasowych", Wydawnictwo Uniwersytetu Marii Curie-Skłodowskiej, Lublin 2008, pp. 109-121 and cf. M. Wojtak, „Rola stylizacji w modyfikowaniu poetyki felietonu”, Prace Filologiczne 2007, Vol. 53, pp. 735-744.
} 
packaging, the issues it discusses are still relevant and presented in a subjective manner"13

The description of the genre commonly presented by many researchers includes the division into internal and external determinants. The former include: the regular appearance of a column and its title, graphic highlighting of text or its fragments, short length ${ }^{14}$. Their involvement in constructing the image is marginal, so they shall not be described here in full. One should therefore focus on external features.

There are no doubts as to the following features of columns: the fact that they combine journalism and literature, the topicality of the issues they deal with, the tendency to parasitize themes, genres and styles, thematic freedom, subjectivity and even partiality, full stylistic freedom and the propensity of journalists to pass judgements in a mocking way.

Although - as Edward Chudziński stresses - "the column is a product of the press par excellence" ${ }^{\prime 15}$ (in the sense that without the press, columns could never have been created), they also bear the hallmarks of literariness since they "employ literary means of expression and use language not only to convey content, but also to affect the reader in emotional and aesthetic terms"16. This genre is thus privileged to use poetic tropes and even has the right to use literary fiction ${ }^{17}$.

A column is supposed to relate to topical issues ${ }^{18}$, which, as it were, prevents it from generating new topics, and journalists who adopt this genre are forced to

${ }^{13}$ M. Wojtak, „Gatunki”, op. cit., p. 212.

${ }^{14}$ See: M. Wojtak, „Gatunki”, op. cit. p. 204, as well as: J. Fras, „Dziennikarski warsztat językowy”, Wydawnictwo Uniwersytetu Wrocławskiego, Wroclaw 1999, p. 85, A. Niczyperowicz, „Przepis”, op. cit., p. 48; E. Sławkowa, op. cit., pp. 308-309, J. Maziarski, „Felieton”, in: „Encyklopedia wiedzy o prasie”, ed. J. Maślanka, Zakład Narodowy im. Ossolińskich, Wroclaw 1976; K. Wolny-Zmorzyński, A. Kaliszewski, W. Furman, „Gatunki dziennikarskie. Teoria - praktyka - język", Wydawnictwa Akademickie i Profesjonalne, Warsaw 2006, p. 89; E. Chudziński, „Felieton. Geneza i ewolucja gatunku”, in: „Dziennikarstwo i świat mediów. Nowa edycja”, ed. Z. Bauer, E. Chudziński, 4. ed., rev., exp., up. ed., Universitas, Cracow 2008, p. 354; T. Klein, „Felieton - niektóre historyczne i teoretyczne aspekty gatunku”, Polonistyka 1983, No. 4, p. 261

${ }^{15}$ E. Chudziński, op. cit., p. 345.

${ }^{16}$ Ibid., p. 355

${ }^{17}$ See: E. Chudziński, op. cit., p. 345, 355; A. Niczyperowicz, „Piękny pasożyt”, op. cit., pp. 82 83, 89-92; R. Jedliński, „Gatunki publicystyczne w szkole średniej”, Wydawnictwa Szkolne i Pedagogiczne, Warsaw 1984, pp. 36, 42-45; P. Stasiński, op. cit., p. 7, J. Maziarski, op. cit., p. 80; K. Wolny-Zmorzyński, A. Kaliszewski, W. Furman, op. cit., p. 88; M. Wojtak, „Gatunki”, op. cit., pp. 202, 205. M. Steciąg perceives this slightly differently; he focuses on the column's journalistic dimension in opposition to the informative character of the media and ignores the literary qualities of this genre - see: M. Steciąg, „Informacja, wywiad, felieton. Sposób istnienia tradycyjnych gatunków w radiu komercyjnym", Uniwersytet Zielonogórski, Zielona Gora 2006, pp. 315-317.

${ }^{18}$ See on the subject of topicality of issues: R. Jedliński, op. cit., p. 36; W. Maziarski, op. cit., p. 80; T. Klein, op. cit., p. 262; E. Chudziński, op. cit., p. 354; K. Wolny-Zmorzyński, A. Kaliszewski, W. Furman, op. cit., p. 88; M. Wojtak, „Gatunki”, op. cit., p. 205; M. Wojtak, „Analiza”, op. cit., p. 109. 
search for inspiration in current affairs. Hence comes the tendency to view columns in the category of a parasitic genre ${ }^{19}$. It is worth noting that topicality is not an absolute determinant and "historical remarks are not forbidden. The columnist does not have to avoid predictions" ${ }^{20}$. There is also no need to make use of a column's ability to adopt any genre and style that can be realized through language, but one may freely do so, unlike in any other genre of journalism ${ }^{21}$.

Apart from the demand to address current affairs, the author has full discretion to choose the subject matter ${ }^{22}$. "A column may be written on any topic, it is the way in which it is approached that determines the genre"23; that is why it may deal, among others, with political, social, cultural, economic or religious issues.

There is a consensus of opinions that the "stylistic boundaries of columns are virtually impossible to determine"24; therefore, stylistic freedom is among their most characteristic features ${ }^{25}$. These kinds of texts may employ a far-reaching language stylization, but always parasitize on literary or functional genres, utilizing their conventions to varying degrees.

Stylistic diversity ties in with another feature - subjectivity ${ }^{26}$. Since "stressing the personal point of view and the subjective character of the conclusions, judgements and commentaries is among the essential features of the genre" $27,-$ as Niczperowicz vividly describes it - the "subjectivism [...] of the columnist might reach the peaks

${ }^{19}$ The word "parasite" in the context of the practice of the column was - as it seems - used for the first time by Cyprian Kamil Norwid in 1851 in the meaning of drawing inspiration from issues already discussed by someone else (C.K. Norwid, “O felietonie felieton”, in: C.K. Norwid, „Pisma wybrane”, Vol. 4: „Proza”, oprac. J.W. Gomulicki, Państwowy Instytut Wydawniczy, Warsaw 1968, p. 185 - after: P. Stasiński, op. cit., p. 9). This word functions as a term in many studies. Its meaning broadened to include the adaptation of genre and style models. In these two variants, the word "to parasitize" and its derivatives are used in this text. On the subject of drawing inspiration from already known topics: P. Stasiński, op. cit., p. 8; T. Klein, op. cit., p. 264; A. Niczyperowicz, „Przepis”, op. cit., p. 46; M. Wojtak, “Gatunki”, op. cit., p. 205; M. Wojtak, “Analiza”, op. cit., p. 109.

${ }^{20}$ M. Wojtak, „Analiza”, op. cit., p. 109.

${ }^{21}$ On the subject of adaptational parasitism: P. Stasiński, op. cit., p. 9; T. Klein, op. cit., p. 262; R. Jedliński, op. cit., p. 37; W. Maziarski, op. cit., p. 80; E. Chudziński, op. cit., p. 354; M. Wojtak, „Gatunki”, op. cit., pp. 204-205; M. Wojtak, „Analiza”, op. cit., p. 109.

${ }^{22}$ On the subject of thematic freedom see for example: P. Stasiński, op. cit., p. 9; R. Jedliński, op. cit., p. 47; E. Chudziński, op. cit., p. 355.

${ }^{23}$ E. Chudziński, op. cit., p. 355.

${ }^{24}$ T. Klein, op. cit., p. 262.

${ }^{25}$ Zob. P. Stasiński, op. cit., p. 9; W. Maziarski, op. cit., p. 80; T. Klein, op. cit., p. 262-263; A. Niczyperowicz, „Przepis”, op. cit., pp. 51-52; R. Jedliński, op. cit., pp. 45-47; K. Wolny-Zmorzyński, A. Kaliszewski, W. Furman, op. cit., p. 88; M. Wojtak, „Gatunki”, op. cit., p. 205; M. Wojtak, „Analiza”, op. cit., p. 110.

${ }^{26}$ Zob. W. Maziarski, op. cit., p. 80; P. Stasiński, op. cit., pp. 10-12; T. Klein, op. cit., p. 265; R. Jedliński, op. cit., p. 47; A. Niczyperowicz, „Przepis”, op. cit., pp. 48, 52; E. Chudziński, op. cit., pp. 254-355; M. Wojtak, „Gatunki”, op. cit., p. 205; M. Wojtak, „Analiza”, op. cit., p. 110; K. Wolny-Zmorzyński, A. Kaliszewski, W. Furman, op. cit., p. 88.

${ }^{27}$ W. Maziarski, op. cit., p. 80. 
of the Himalayas"28. Partiality, intellectual provocation, stressing the autonomy of views, all these are almost considered to be among the responsibilities of the author.

A mocking tone may be regarded as the consequence of personal approach ${ }^{29}$ :

The columnist [...] maintains a sceptical detachment from the subject of his/her deliberations. It is detachment, irony and self-irony that results in a satirical approach, parody or pastiche - the characteristic determinants of the attitude specific to a column ${ }^{30}$.

Such texts display a consistent tendency towards irony, satire, lampoon, grotesque, sarcasm, contrariness, scandalizing, making controversial arguments, spiteful criticism or presenting humorous observations.

\section{Predicting the capacity of columns for image creation}

As can be seen, individual authors pay particular attention to informality, which manifests itself in subjectivity and serves persuasion (P. Stasiński), thematic parasitism and literariness in the text's structure (A. Niczyperowicz), shaping the genre's style through individual styles (Sławkowa), using all kinds of adaptational models in different manners (M. Wojtak). Such ways of approaching the problem reveal the column's dependence, understood as the need to draw topics and the ways of presenting them from both social life and literary tradition (A. Niczyperowicz, M. Wojtak), but also the nearly unlimited ability to search for sources of inspiration, subject matter and form. These determinants give grounds to conclude that readers may find a columnist to be creative, well-read, well acquainted with recent events and subjective. This subjectivism and individual nature of style (P. Stasiński, E. Sławkowa) enables the authors to express their own personality, hence it may be expected that their personal traits would be suggested.

The inclusion of the generic determinants which can be found in the majority of research in such predictions reinforces these expectations and supplements the hypothesis with the conclusion that a columnist may also seem malicious and ironic.

The extent to which readers attribute the above-mentioned traits to the columnists themselves shall be verified by confronting the hypothesis with the results of empirical research.

${ }^{28}$ A. Niczyperowicz, „Przepis”, op. cit., p. 52.

${ }^{29}$ Zob. P. Stasiński, op. cit., pp. 9-10; W. Maziarski, op. cit., p. 80; T. Klein, op. cit., p. 262; A. Niczyperowicz, Przepis, op. cit., pp. 48, 52; R. Jedliński, op. cit., pp. 36, 47; E. Chudziński, op. cit., p. 356; K. Wolny-Zmorzyński, A. Kaliszewski, W. Furman, op. cit., p. 88; M. Wojtak, „Gatunki”, op. cit., p. 206; M. Wojtak, “Analiza”, op. cit., p. 110.

${ }^{30}$ E. Chudziński, op. cit., p. 356. 


\section{Image}

Image is understood as "the audience's impression of a person, company or institution; this impression is not real, precise or detailed, but comprises many accidental details in a fragmentary way; their differences are blurred" 31 . The fact that "An image is not a faithful copy of the subject, because the process of perception is subjective and active at the same time"32. An image is therefore actively constructed by the recipient on the basis of verbal, visual, sound, tactile and spatial messages, or on the basis of widely-understood context. On the other hand, image is always more or less consciously designed, and its specification is always among the communicative aims of the sender, in columns, too.

\section{Research perspective}

The perspective of rational constructivism was employed in planning the empirical research, as it differentiates between speaking and communicating ${ }^{33}$ : "While speaking pertains to what is said, communicating refers to how it is said, and what is communicated with what and how it is said"34. Michael Fleischer illustrates this division with the example of a conversation between two young people who react to the sight of a building and the sign of the Wroclaw University of Economics:

He: What's that?

She: A university.

He: And what exactly is that?

She: Well, studies.

The young man said what he said (= statement), but he communicated that he had no idea what a university is ${ }^{35}$.

Likewise, a columnist, regardless of the subject he/she deals with in a given text, communicates about himself as an author of that statement.

\footnotetext{
${ }^{31}$ K. Wojcik, „Public Relations. Wiarygodny dialog z otoczeniem. Podręcznik dla teoretyków. Poradnik dla praktyków", Wydawnictwo Placet, Warsaw 2009, p. 41.

${ }^{32}$ W. Budzyński, „Wizerunek równoległy. Nowa szansa promocji firmy i marki”, Wydawnictwo Poltext, Warsaw 2008, p. 11.

${ }^{33}$ M. Fleischer, „Typologia komunikacji”, Wydawnictwo Primum Verbum, Lodz 2012.

${ }^{34}$ Ibid., p. 29.

${ }^{35}$ Ibid.
} 
The method employed makes it possible to objectively recreate the traits communicated by authors of texts which make up the image emerging from the column. A survey conducted using a homogeneous group of respondents was used.

\section{The course of the empirical research}

The surveys in which the respondents described the image of Krzysztof Varga and Szymon Hołownia (some respondents were asked to indicate the traits of $\mathrm{K}$. Varga, others the traits of S. Hołownia) were conducted twice: in November 2011 during a lecture for first year students of journalism and social communication at the University of Lodz, and in May 2012 during classes for students of journalism and social communication at the University of Wroclaw $\left(1^{\text {st }}\right.$ and $2^{\text {nd }}$ year), Kazimierz Wielki University in Bydgoszcz ( $1^{\text {st }}$ year), and among students of Polish philology at the University of Lodz ( $1^{\text {st }}$ year). Only students from the first two years of these two majors participated in the surveys. Such a procedure was dictated by the assumption that their communicative and language competences are sufficient for conducting reliable research, and their greater eloquence than in the case of students from other majors would make it easier to answer the questions. Students of higher years were not engaged due to the fact that their competences and awareness of language, communication and genres of journalism were predicted to be too high. The engagement of students from two related fields of study ensured the homogeneity of the trial.

The following sequence of tasks was employed. The respondents read a column, then they described which traits of the author emerged from the text, and in the next task they listed the language indicators of the personality traits they described. The first question read: "Which words would you use to describe the author Krzysztof Varga/Szymon Hołownia on the basis of the column you have just read?". Five bullet points printed under the question suggested the need to list five traits. Having completed the task, the respondents answered the next question on a separate sheet of paper. They were asked to indicate which parts of the text contributed to the choice of attributes ${ }^{36}$. However, as the answers obtained in this task are insignificant from the point of view of this text, they shall not be discussed here. ${ }^{37}$

\footnotetext{
${ }^{36}$ The task read: "For every personality trait of Krzysztof Varga you indicated, please write out words/sentences/fragments from the text which determined the choice of that attribute". In the case of S. Hołownia's columns, the task was modified accordingly.

${ }^{37}$ In this text, the course of the research, the structure of the survey's questionnaire and its results are described in brief, but as exhaustively as the context demands; this stems from, among others, length limitations. Full details on the course and realisation of the survey with the exact numerical
} 
The participants were not informed about the content of the subsequent tasks so that they would not read them in a way making it easier to answer the questions. The time for answering was unlimited, but did not exceed 15-20 minutes. The column was presented to the respondents as a copy of the original page from the weekly/supplement in which it was published. The picture of the author was visible and his identity was provided.

Each time, seven recently published columns by a given author were used, to take into account the feature of topicality of the issues. In the case of Krzysztof Varga, these included the texts published in Duzy Format, a supplement to Gazeta Wybocza; the cycle of columns is entitled Kajet konesera ${ }^{38}$ (Connoisseur's notebook). In the case of Szymon Hołownia, the columns entitled Sady ostateczne (Last judgements) published in Newsweek Polsk ${ }^{39}$ weekly were used. The first columnist deals with cultural issues, whereas the other with religious ones. The thematic diversity makes it possible to verify the extent to which the subject matter affects the image of the author.

56 respondents participated in the survey; half of them read Krzysztof Varga's texts, the other half - those written by Szymon Hołownia.

\section{Results of the empirical research}

The collected data was subjected to a simple frequency analysis whose results are provided in the tables below. The open nature of the question caused high lexical diversity; the answers were encoded and classified into the semantic categories presented in the second column ("Columnist's traits") ${ }^{40}$. Then, the number

data regarding respondents, their gender, majors, other variants and all details concerning the study in question can be found respectively in: A. Barańska-Szmitko, „Wizerunek Krzysztofa Vargi komunikowany słowem. Reprezentacja językowa cech przypisywanych autorowi tekstu”, in: „Badanie i projektowanie komunikacji 2", ed. M. Grech, A. Siemes, Wydawnictwo Uniwersytetu Wrocławskiego, Wroclaw 2013, pp. 155-177 and A. Barańska-Szmitko, „Wizerunek Szymona Hołowni komunikowany w jego felietonach”, in: „Badanie i projektowanie komunikacji 3” [in print]. The data provided here is presented according to the information included in the above texts.

${ }^{38} \mathrm{~K}$. Varga's columns from the following issues of Duży Format were used: 22.03.2012, 29.03.2012, 12.04.2012, 19.04.2012, 26.04.2012, 10.05.2012, 17.05.2012, 1.09.2011, 8.09.2011, 15.09.2011, 22.09.2011, 25.09.2011, 29.09.2011, 6.10.2011. Each column was read by a couple of respondents.

${ }^{39} \mathrm{~S}$. Hołownia's columns from the following issues of the weekly were used: 28.03 .2012 , 10.04.2012, 16.04.2012, 23.04.2012, 27.04.2012, 7.05.2012, 14.05.2012, 24.07.2011, 31.07.2011, 07.08.2011, 15.08.2011, 18.09.2011, 25.09.2011, 02.10.2011. Each column was read by a couple of respondents.

${ }^{40}$ Lexical diversity was realised in such a way that the attribute "direct" was realised with lexemes such as: resolute, nonconformist, has definite views, is not afraid of voicing his opinion, has 
of all indications within the range of a single trait was provided; the next column features the percentage of respondents who indicated the same trait, measured against the total number of respondents (28). Therefore, the last two columns add up neither to 28 nor to $100 \%$. The "other" row includes indications listed by the participants less than two times.

Table 1. Answers to the question: "Which words would you use to describe the author Krzysztof Varga on the basis of the column you have just read?"

\begin{tabular}{|l|l|c|c|c|c|}
\hline \multirow{2}{*}{ No. } & \multirow{2}{*}{ Columnist's trait } & \multicolumn{2}{c|}{ Total indications } & \multicolumn{2}{c|}{ Total respondents } \\
\cline { 3 - 6 } & & $\mathrm{n}$ & $\%$ & $\mathrm{n}$ & $\%$ \\
\hline & direct & 23 & 17,42 & 16 & 59,26 \\
\hline & well-read & 20 & 15,15 & 15 & 55,55 \\
\hline & ironic & 16 & 12,12 & 14 & 51,85 \\
\hline & intelligent & 11 & 8,33 & 11 & 40,74 \\
\hline & communicative & 8 & 6,06 & 7 & 25,93 \\
\hline & witty & 7 & 5,30 & 7 & 25,93 \\
\hline & observant & 7 & 5,30 & 6 & 22,22 \\
\hline & critical & 6 & 4,55 & 5 & 18,52 \\
\hline & provocative & 4 & 3,03 & 4 & 14,81 \\
\hline & detached & 3 & 2,27 & 3 & 11,11 \\
\hline & patriotic & 3 & 2,27 & 3 & 11,11 \\
\hline & a realist & 3 & 2,27 & 3 & 11,11 \\
\hline & journalistic & 3 & 2,27 & 3 & 11,11 \\
\hline & a fan of Woody Allen & 2 & 1,52 & 2 & 7,41 \\
\hline & tolerant & 2 & 1,52 & 2 & 7,41 \\
\hline & idealistic & 2 & 1,52 & 2 & 7,41 \\
\hline & consistent & 2 & 1,52 & 2 & 7,41 \\
\hline & atheist & 2 & 1,52 & 2 & 7,41 \\
\hline & other & 8 & 6,06 & 6 & 22,22 \\
\hline & Total & 100 & & \\
\hline
\end{tabular}

Source: own work on the basis of: A. Barańska-Szmitko, "Wizerunek Krzysztofa Vargi komunikowany słowem. Reprezentacja językowa cech przypisywanych autorowi tekstu" in: "Badanie i projektowanie komunikacji 2", ed. M. Grech, A. Siemes, Wydawnictwo Uniwersytetu Wrocławskiego, Wroclaw 2013, pp. 167-168.

an opinion and voices it without inhibition and others. Due to length limitations of this text and its aim, the tables ignore lexical variants and present the lexeme which represents the given attribute. Sources of full data are under the tables. 
The image of Krzysztof Varga constructed on the basis of a text whose authorship was known to respondents comprises mostly traits such as: direct $(17.42 \%$ of total indications), well-read (15.15\%), ironic (12.12\%) and intelligent (8.33\%). These attributes were provided by the following percentages of respondents: $59.26 \%, 55.55 \%, 51.85 \%$ and $40.74 \%$. This means that more than half, or close to half of readers perceived the author as direct, ironic, intelligent and erudite. The columnist's attributes indicated by more than $1 / 4(25.93 \%)$ of respondents include communicative and witty (respectively $6.06 \%$ and $5.3 \%$ of all indications). More than $1 / 5(22.22 \%)$ or almost $1 / 5(18.52 \%)$ of respondents perceived the author as observant (5.3\% of total indications) and critical (4.55\% of indications). Other traits (provocative, detached, patriotic, a realist, journalistic, Allen's fan, tolerant, idealistic, consistent, atheist) were indicated by less than $15 \%$ of participants, and each of them constituted less than $3.03 \%$ of all indications.

Table 2. Answers to the question: "Which words would you use to describe the author Szymon Hołownia on the basis of the column you have just read?"

\begin{tabular}{|l|l|c|c|c|c|}
\hline \multirow{2}{*}{ No. } & \multirow{2}{*}{ Columnist's trait } & \multicolumn{2}{c|}{ Total indications } & \multicolumn{2}{c|}{ Total respondents } \\
\cline { 3 - 6 } & & $\mathbf{n}$ & $\mathbf{\%}$ & $\mathbf{n}$ & $\mathbf{\%}$ \\
\hline 1 & & 3 & 4 & 5 & 6 \\
\hline & religious & 17 & 12,78 & 17 & 60,71 \\
\hline & defends his beliefs & 14 & 10,53 & 9 & 32,14 \\
\hline & intelligent & 10 & 7,52 & 10 & 35,71 \\
\hline & erudite & 9 & 6,77 & 9 & 32,14 \\
\hline & critical & 9 & 6,77 & 9 & 32,14 \\
\hline & respectful & 8 & 6,01 & 8 & 28,57 \\
\hline & communicative & 7 & 5,26 & 6 & 21,43 \\
\hline & ironic & 6 & 4,51 & 6 & 21,43 \\
\hline & observer & 5 & 3,76 & 5 & 17,86 \\
\hline & inquisitive & 4 & 3,01 & 4 & 14,29 \\
\hline & sensitive & 4 & 3,01 & 4 & 14,28 \\
\hline & committed & 4 & 3,01 & 4 & 14,28 \\
\hline & tired with the media & 4 & 3,01 & 2 & 7,14 \\
\hline & detached & 4 & 3,01 & 4 & 14,28 \\
\hline & knowledgeable & 3 & 2,26 & 3 & 10,71 \\
\hline & moralistic & 3 & 2,26 & 3 & 10,71 \\
\hline & idealistic & 2 & 1,5 & 2 & 7,14 \\
\hline & aware of his rights & 2 & 1,5 & 2 & 7,14 \\
\hline
\end{tabular}




\begin{tabular}{|l|l|c|c|c|c|}
\hline 1 & \multicolumn{1}{|c|}{2} & 3 & 4 & 5 & 6 \\
\hline & consistent & 2 & 1,5 & 1 & 3,57 \\
\hline & conservative & 2 & 1,5 & 1 & 3,57 \\
\hline & reactionary & 2 & 1,5 & 1 & 3,57 \\
\hline & other & 12 & 9,02 & 10 & 35,71 \\
\hline & Total & 133 & & & \\
\hline
\end{tabular}

Source: own work on the basis of: A. Barańska, "Wizerunek Szymona Hołowni komunikowany w jego felietonach", in: "Badanie i projektowanie komunikacji 3"[in print].

Religious faith appears to be the most distinctive trait of Szymon Hołownia's image. The attribute religious was chosen by more than half of all readers $(60.71 \%)$, and it constituted $12.78 \%$ of all indications. Defends his beliefs, intelligent, erudite, critical and respectful were among strongly represented characteristics (respectively : $32.14 \%, 35.71 \%, 32.14 \%$, 32.14\%, 28.57\%), yet they were given by less than half of respondents (respectively: 32.14\%, 35.71\%, 32.14\%, 32.14\%, $28.57 \%$ ). Communicative, ironic, observer were listed by more than, or almost $1 / 5$ of respondents (respectively: $21.43 \%, 21.43 \%, 17.86 \%$ ) and constituted respectively $5.26 \%, 4.51 \%, 3.76 \%$ of total indications. Other traits (inquisitive, sensitive, committed, tired with the media, detached, knowledgeable, moralistic, idealistic, aware of his rights, consistent, conservative, reactionary) were noticed by less than $15 \%$ of participants and represented less than $3.01 \%$ of total indications.

\section{Summary and conclusions}

Comparing the two images determined by respondents on the basis of the columns they read, it is clear that some traits turn out to be common for both authors (well-read, erudite, ironic, intelligent, communicative, and among the less frequently mentioned: consistent, detached and idealistic), which could indicate that the columns generate these attributes, deriving from determinants such as: thematic discretion, searching for inspiration in already existing information and emphasizing one's own point of view in a mocking way. However, since the first three traits are attributed by more than half, or almost half of readers to Krzysztof Varga, and only by 1/3 to Szymon Hołownia, it seems that the genre has an extraordinary potential to communicate these traits, but the extent to which this potential is fulfilled depends on the author. None of a column's features may be deemed directly responsible for the epithet communicative.

It seems interesting that among the traits attributed to the authors subjective is never directly mentioned. The readers very often notice the distinctive form of expression (direct, defending his beliefs) or critical attitude to the issues discussed 
(critical) instead of the author's partiality. On the other hand, the subjectivism-related tendency for irony, satire, the grotesque etc. is noticeable, which is indicated by ascribing attributes such as ironic, witty or provocative to the columnists.

The fact that Szymon Hołownia was frequently described as "religious" suggests that the choice of themes significantly affects the image of the author that is inferred from the text by readers. Perhaps the attribute well-read ascribed to Krzysztof Varga by over half of respondents results from the fact that he discusses cultural topics, including those pertaining to literature. Therefore, the freedom to choose any subject matter creates opportunities for communicating an image.

The other epithets given by respondents (Varga: patriotic, a realist, journalistic, Allen's fan, tolerant or atheist; Hołownia: respectful, observer, inquisitive, sensitive, committed, tired with the media, knowledgeable, moralistic, aware of his rights, traditional or conservative) seem to be an expression of the author's personality and result from the column's capacity to express the author's character; this is possible thanks to the determinants of the genre such as stylistic freedom, subjectivity, emphasis on a personal point of view. The aforementioned attributes are not derived from any of the column's features, but indirectly result from a few of them.

Thus, the image of the authors was mostly influenced by determinants such as subjectivity and, to some extent, stylistic freedom, yet it is essential that this influence is indirect. The features of the column quite clearly translate into traits attributed to its author, which is noticeable in the case of emphasizing the writer's attitude, for example in an ironic manner. Although the features of thematic and genre-specific parasitism, as well as of drawing on the capacities of journalism and literature, suggest that the authors should be regarded as well acquainted with current events and creative, the respondents did not notice any such traits in the columnists. The freedom to choose a topic is vital, because the choice of issues discussed in the cycle may decide which traits are attributed to the author.

It therefore seems that the inclination to pass judgements, and the contents of the columns are paramount in terms of creating the image of the author. While the group of most frequently ascribed traits is limited, the differences in the proportions of their occurrence in the works of the given authors show that it is easy to communicate recurring characteristics in this genre, it is the author who decides on the extent to which that potential is realised. A column also enables its author to manifest their personality traits, even though the current results show that such attributes are less frequently indicated than others.

The research presented in this text was continued on a larger scale with a sample of over 200 people, and included two more columnists (Magdalena Środa, Piotr Zaremba). The analysis of its findings may reinforce the conclusions presented here ${ }^{41}$.

\footnotetext{
${ }^{41}$ From the beginning, the project was carried out with four columnists in mind. Partial results concerning two of them are presented in this study. The research discussed here and its results are
} 


\section{Bibliography}

Barańska-Szmitko A., „Wizerunek Krzysztofa Vargi komunikowany słowem. Reprezentacja językowa cech przypisywanych autorowi tekstu”, in: „Badanie i projektowanie komunikacji 2”, ed. M. Grech, A. Siemes, Wydawnictwo Uniwersytetu Wrocławskiego, Wroclaw 2013, pp. 155-177.

Barańska-Szmitko A., „Wizerunek Szymona Hołowni komunikowany w jego felietonach”, in: „Badanie i projektowanie komunikacji 3”, ed. M. Wszołek, Wydawnictwo Libron, Wroclaw 2014, pp. 173-196.

Budzyński W., „Wizerunek równoległy. Nowa szansa promocji firmy i marki”, Wydawnictwo Poltext, Warsaw 2008.

Chudziński E., „Felieton. Geneza i ewolucja gatunku”, in: „Dziennikarstwo i świat mediów. Nowa edycja”, ed. Z. Bauer, E. Chudziński, ed. 4, rev., exp., up. ed., Universitas, Cracow 2008, pp. 345-360.

Fleischer M., „Ogólna teoria komunikacji”, Wydawnictwo Uniwersytetu Wrocławskiego, Wroclaw 2007.

Fleischer M., „Typologia komunikacji”, Wydawnictwo Primum Verbum, Lodz 2012.

Fras J., „Dziennikarski warsztat językowy”, Wydawnictwo Uniwersytetu Wrocławskiego, Wroclaw 1999.

Grech M., „Badanie wizerunku - metody ankietowe. Metodologia badań”, in: „Badanie wizerunku: ludzie, marki, branże”, ed. M. Grech, Wydawnictwo Primum Verbum, Lodz 2012, pp. 11-26.

Jedliński R., „Gatunki publicystyczne w szkole średniej”, Wydawnictwa Szkolne i Pedagogiczne, Warsaw 1984.

Klein, „Felieton - niektóre historyczne i teoretyczne aspekty gatunku”, Polonistyka 1983, No. 4, pp. 97-104.

Maziarski J., „Felieton”, in: „Encyklopedia wiedzy o prasie”, ed. J. Maślanka, Zakład Narodowy im. Ossolińskich, Wroclaw 1976.

Niczyperowicz A., „Przepis na felieton”, in: „Abecadło dziennikarza”, ed. A. Niczyperowicz, Kontekst, Poznan 1996, pp. 45-57.

Niczyperowicz A., „Felieton. Piękny pasożyt”, in: „Dziennikarstwo od kuchni”, ed. A. Niczyperowicz, TS, Poznan 2001, pp. 81-94.

Norwid C.K., „O felietonie felieton”, in: C.K. Norwid, „Pisma wybrane”, Vol. 4: „Proza”, ed. J.W. Gomulicki, Państwowy Instytut Wydawniczy, Warsaw 1968

Siemes A., „Jak badać komunikację”, Communication Design Magazine 2011, Vol. 1 [online], http://www.cd-magazine.uni.wroc.pl/artykul/jak_badac_komunikacje/ [access: 6.01.2014].

part of a larger project which pursues several variants of the research and includes simultaneously conducted surveys concerning four columnists: Krzysztof Varga, Szymon Hołownia, Magdalena Środa and Piotr Zaremba. The beginning of the research (autumn 2011 and part of the surveys from May 2012) was a pilot study. The results presented here are therefore partial. While this text was being prepared, the final analysis and interpretation of the results of all variants of the study was in progress; the results were obtained for all four columnists during every relevant time period (spring 2012, spring 2013, autumn 2013). An equal number of texts for every author was taken into consideration; these texts came from the same most recent period and were read by an equal number of respondents from a globally homogeneous group. The study of the image of the column's author whose identity is known, conducted in a group of over 200 people, is among the simultaneously pursued variants of the overall research. 
Sławkowa E., „Style współczesnego felietonu (Z zagadnień stylistyki gatunku)”, in: „Gatunki mowy i ich ewolucja”, Vol. 1: „Mowy piękno wielorakie”, ed. D. Ostaszewska, Wydawnictwo Uniwersytetu Wrocławskiego, Katowice 2000, pp. 305-315.

Stasiński P., „Poetyka i pragmatyka felietonu”, Zakład Narodowy im. Ossolińskich, Wroclaw 1982, pp. 5-17.

Steciąg M., „Informacja, wywiad, felieton. Sposób istnienia tradycyjnych gatunków w radiu komercyjnym", Uniwersytet Zielonogórski, Zielona Gora 2006.

Wojcik K., „Public Relations. Wiarygodny dialog z otoczeniem. Podręcznik dla teoretyków. Poradnik dla praktyków”, Wydawnictwo Placet, Warsaw 2009.

Wojtak M., „Analiza gatunków prasowych”, Wydawnictwo Uniwersytetu Marii Curie-Skłodowskiej, Lublin 2008.

Wojtak M., „Gatunki prasowe”, Wydawnictwo Uniwersytetu Marii Curie-Skłodowskiej, Lublin 2004.

Wojtak M., „Rola stylizacji w modyfikowaniu poetyki felietonu”, „Prace Filologiczne” 2007, Vol. 53, pp. 735-744.

Wolny-Zmorzyński K., Kaliszewski A., Furman W., „Gatunki dziennikarskie. Teoria - praktyka - język", Wydawnictwa Akademickie i Profesjonalne, Warsaw 2006.

Anna Barańska-Szmitko

\section{The Capacities and Limitations of the Newspaper Column as a Tool for Creating the Image of Its Author}

\section{(Summary)}

The aim of this paper is to verify the capacities and limitations of the newspaper column (understood as a genre) as a tool for creating the image of its author. In the paper, the distinguishing features of a column are first presented, and then a hypothesis is proposed for predicting which attributes of its author may be generated by the column's features. This hypothesis is juxtaposed with the results of empirical research. The main task of this research was to read the texts of one of two Polish columnists - Krzysztof Varga and Szymon Hołownia - and subsequently answer questions indicating the authors' attributes. This procedure made it possible to recreate the image of the text's author. The results demonstrated the influence of the column's distinguishing features on the image of its author inferred by readers.

Keywords: column, image, image researches. 